\title{
Animeldelse: Folkeret på godt og på ondt
}

Af Henrik Døcker

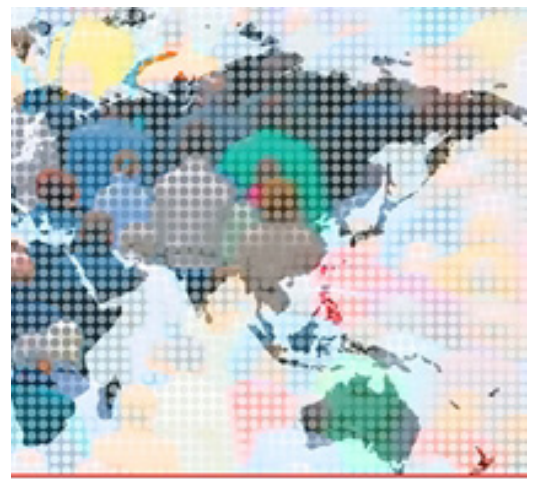

FOLKERET

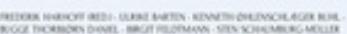

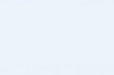

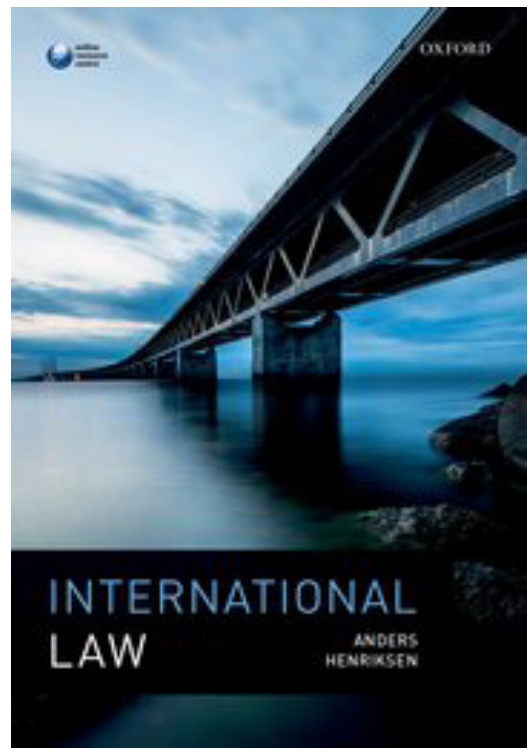

Frederik Harhoff (red.): Folkeret. Hans Reitzels Forlag, 2017. 590 s.

Anders Henriksen: International Law. Oxford University Press, 2017. 346 s.

Daniel Högger \& Cristina Verones (red.) Völkerrecht kompakt. Verlag Neue Zürcher Zeitung, 2016. 176 s. 
Folkeretten fletter sig jævnligt ind i storpolitikken, men det er hyppigt svært at få rede på disciplinens objektive substans. Ligesom det ofte kniber med eksempler på, at stater har bøjet sig for andre staters pres baseret på argumenter om folkeretsstridig adfærd. Det spørgsmål trænger sig på, om folkeretten i virkeligheden regulerer ret meget i nutidens komplicerede magtspil?

Det kan indvendes, at det ikke er fuldstændig fair at læse tre bøger som disse med andet end skarptslebne folkeretlige briller, sådan som denne anmelder ikke har gjort. Men omtalen af dem gives ud fra den betragtning, at der kan være behov for en bredere kreds at få indsigt $\mathrm{i}$, hvordan folkerettens begreber defineres, og $\mathrm{i}$ hvilket omfang retsafgørelser inden for denne emnekreds kan tilskrives betydning.

Professor emeritus Frederik Harhoff har haft fem indsigtsfulde jurister som medforfattere til en meget omfattende lærebog, der dog ikke slår den hidtidige rekord, hvad angår sideantallet, nemlig 1. udgaven af Ole Spiermanns Moderne folkeret efter det 20. århundrede fra 1999: 641 sider (i efterfølgende udgaver dog nedbragt til 517 sider). Folkeretsjuristerne vil nok fnyse ad den slags irrelevant 'talmagi', men det er bemærkelsesværdigt at slå så store brød op i betragtning af, hvor lille faget folkeret er på universitetet. Bogen er imidlertid blevet til for at give en aktuel, forskningsbaseret fremstilling som afløser for en lærebog fra 2003, såmænd forfattet af Harhoff og Spiermann - foruden Ole Espersen.

\section{Folkerettens aktører}

Bogens indledende kapitel har en virkelig nyskabende tilgang til emnet, idet der gives detaljeret besked om fire 'holdninger' til folkeretten som sådan, repræsenteret ved:

1) Benægterne (som altså slet ikke betragter folkeret som egentlig ret, ikke mindst fordi der ikke findes nogen verdensdomstol, som kan gennemtvinge afgørelser, der går denne og hin stat imod).

2) Naturretstænkerne (der holder på, at der i naturen findes en særlig ret, og at der ikke findes 'retstomme rum', hvad der let kan lede hen til, at den ret, der udfoldes på vor klode, i virkeligheden må underordne sig nogle moralske normer).

3) Fortalerne (der støtter sig på, at staterne lader sig påvirke af $\mathrm{fx}$ internationale domstoles afgørelser, indarbejdede normer og traktater).

4) Kritikerne (som hæfter sig ved folkerettens horisontale karakter, dvs. det er den ret, der gælder mellem staterne modsat det hierarki, der hersker inden for staterne, hvortil kommer folkerettens myriader af regler, der mest er kendt, fordi de overtrædes - uden at der findes rigtig effektive midler til at imødegå dette).

Der er solide portioner vigtig viden at hente, også af historisk og retshistorisk art i dette indledende kapitel, men det er meget af ofre 45 sider af en lærebog på dette - også i betragtning af at et følgende kapitel på ca. 30 sider omhandler folkerettens historie som sådan.

Dog er det her bl.a. spændende at læse om Osmannnerriget og dets sam- 
menbrud såvel som Østrig-Ungarns opløsning. Efter Første Verdenskrig tilvejebragtes en nyordning særligt i Europa: Efter idé af den amerikanske præsident Woodrow Wilson oprettedes den første større internationale organisation Folkeforbundet - med hans siden så berømte ' 14 punkter', der i øvrigt var båret af ideen om folkenes selvbestemmelsesret. Dette sidste skulle efter datidig opfattelse dog kun tilkomme europæiske stater, ligeså lidt som tabermagternes mindretal.

Væsentligt er, at de internationale organisationer tillægges, hvad der kaldes folkeretssubjektivitet, dvs. samme kompetencer som folkerettens helt typiske aktører - eller mere 'teknisk' subjekter: staterne. Som bogen påpeger, kan en sådan organisation indgå i retlige forbindelser, der adskiller sig fra summen af medlemsstaternes forpligtelser.

Der gælder imidlertid forskelligartede og indviklede regler for organisationerne. Fx er FN immun over for søgsmål, hvorfor et erstatningskrav fra efterladte fra Srebrenica-folkedrabet rettet mod den nederlandske militærenhed, som indgik i FN's militærstyrke i Bosnien-Hercegovina, måtte afvises. Derimod pålagde en nederlandsk domstol Holland ansvar for drabet på en mindre del af de i alt 8.000 bosniske drenge og mænd, som proserbiske styrker henrettede. Denne del af dramaet er mærkelig nok forbigået både i Harhoffs bog og $\mathrm{i}$ Anders Henriksens.

\section{Manglende konsekvens}

Hermed springer vi ind i et aspekt, som har optaget nærværende anmelder: En mangel på konsekvens i medtagelsen af eksempler på an- vendelse og effekt af denne og hin folkeretsregel.

Folkeret byder forfriskende på mange eksempler, sat med andre typer end den almindelige tekst, men det er ikke nødvendigvis konkrete tilfælde eller sager. Ikke helt sjældent bliver læseren spist af med en afkortet version, som ikke giver fuld besked med konkrete tvister.

Som nu den meget omtalte afgørelse fra Den Permanente Voldgiftsdomstol i Haag, hvori Kinas krav på store bidder af Det Sydkinesiske Hav blev afvist - til glæde for sagsøgeren Filippinerne og de filippinske fiskere, der var blevet vist bort fra deres fiskebanker af kineserne. Bogen taler eufemistisk blot om en omfattende analyse af regler i FN's havretskonvention.

Når det i en tillægsprotokol til Geneve-konventionerne hedder, at tæppebombninger er forbudt, savnes en definition eller i det mindste nogle eksempler (typisk fra dem over Tyskland i Anden Verdenskrigs slutfase). I det hele taget er det yderst småt med eksempler i omtalen af krigens folkeret - nu til dags kaldet den humanitære folkeret.

Det er jo meget godt med alle disse regler - det være sig FN’s, Røde Kors' eller andres, men i hvilket omfang bliver de overholdt? Det er ligesom ikke rigtig folkeretslærebøgernes ærinde at svare overskueligt på det. Men vi kan få et fingerpeg fx i kapitlet om ansvar for folkeretsbrud og iværksættelse af strafansvar.

En masse teori er udviklet af The International Law Commission under FN, som besynderlig nok oversættes ved FN's Lovkommission, selv om det reelt er FN's Folkeretskommission, der in- 
genlunde befatter sig med love i enkelte stater. I de 40 sider, der i Harhoff-bogen drejer sig om folkeretstvister og disses bilæggelse, bringes kun ganske få ikke videre slagkraftige eksempler. Intetsteds i nogle af de to lærebøger får man fx et overblik over sådan noget som antallet af Den Internationale Domstols (ICJ) afgørelser.

\section{Geneve-konventionerne}

Spredt rundt i denne bog er der imidlertid henvist til den vigtige afgørelse fra domstolen i Nicaragua-sagen i 1986 - som på den anden side først egentlig (og kort) beskrives på side 365; hos Henriksen gives der end ikke et sådant resumé. Ved at udlægge miner i Nicaraguas havne og støtte de såkaldte contra'ers oprør mod den nicaraguanske regering blev USA dømt for brud på det generelle magtanvendelsesforbud.

Det forklares ikke, at domstolen støttede sig på folkeretlig sædvaneret frem for FN-pagten, at USA obstruerede sagen og i øvrigt aldrig betalte den skadeserstatning, det blev pådømt. Hos Henriksen er det ikke muligt trods mange små henvisninger at få noget klart overblik over Nicaragua-dommen.

Andre afgørelser fra ICJ kan man hitte under de respektive folkeretlige delikter eller emnekredse, sådan som det sømmer sig for den type lærebøger. En almen interesse har det imidlertid at få opregnet nogle eksempler på ICJ-domme, som virkelig har flyttet noget. Dem er der ikke ret mange af, men de to hvor Danmark var involveret - begge gange mod Norge - drejede sig suverænitetstvister i og ved Grønland.
I Østgrønlandssagen fra 1933 gav ICJ Danmark mod et norsk krav medhold $i$ at have rådighedsret over Østgrønland ved både at vise vilje og evne til at herske dér, og i striden om territorialfarvandet omkring den norske $\varnothing$ Jan Mayen og Grønland anviste ICJ et midtlinjeprincip, idet der dog blev givet lidt 'rabat' til den norske $\varnothing$.

Harhoff gør meget ud af de fire Geneve-konventioner med tillægsprotokollers myriader af regler og hvordan, der sondres mellem jus ad bellum og jus in bello. Førstnævnte oversætter han beklageligvis noget misvisende 'retten mod krig', nej det betyder retten til krig - altså de specielle tilfælde, hvor FN-pagtens forbud herimod kan tilsidesættes, nemlig i selvforsvar, eller hvis FN's Sikkerhedsråd har sanktioneret det. Sidstnævnte begreb dækker de regler, som staterne skal følge i krig, altså krigens folkeret eller, som det moderne udtryk lyder: den humanitære folkeret.

Her mangler i forbløffende grad eksempler på reglernes anvendelse eller ikke-overholdelse. Fx blev de i stor stil overholdt i Falklandskrigen (hurtig udveksling af syge og sårede krigsfanger). Vi hører end ikke om My Lai-massakren (hverken hos Harhoff eller Henriksen), hvor en amerikansk løjtnant under Vietnam-krigen var ansvarlig for omkring 400 civile vietnameseres henrettelse og efterfølgende blev dømt ved en amerikansk domstol (først livsvarigt fængsel og så benådet).

De internationale straffetribunaler vedrørende Eksjugoslavien (ICTY) og Rwanda (ICTR) får en forbavsende kortfattet omtale i begge bøger. Der er dog masser af interessant folkeretsan- 
vendelse her! Det var her enkeltpersoner for første gang i retshistorien blev dømt for folkedrab (oberst Theoneste Bagasora i Rwanda, general Radoslav Krstic i Bosnien-Hercegovina. Anmelderens tilføjelse).

Her får vi hos Harhoff (om ICTY) for en gangs skyld noget statistik, men dog ikke på hvor mange, der blev dømt (den seneste statistik efter bogens udgivelse: 89; for ICTR 62). Begge tribunaler, nedsat ved FN-sikkerhedsrådsresolutioner, dømte hovedansvarlige for et eller flere af tre internationale delikter - folkedrab, krigsforbrydelser eller forbrydelser mod menneskeheden - under folkedrabene i henholdsvis 1994 og 95 . Kun et fåtal dog for folkedrab som sådan - det skulle vise sig vanskeligt at bevise.

En interessant diskussion, som ikke tages op af nogen af forfatterne, kunne være, hvordan folk fra Rwanda kunne dømmes for krigsforbrydelser, når der ikke i traditionel forstand var krig i dette land. Tutsier og moderate hutuer blev nedslagtet af hutu-flertallet, men det var ikke formeret $\mathrm{i}$ bevæbnede enheder under kommando.

\section{Retfærdige retsopgør}

Tribunalerne blev nedsat, fordi hverken Bosnien eller Rwanda var i stand til noget retsopgør, som for de vigtigste aktører kunne forventes at blive retfærdigt.

Sådan var det også, da Nazityskland og Japan efter Anden Verdenskrig brød sammen, og de allierede sejrsmagter besluttede at nedsætte Nürnberg- og Tokyo-tribunalerne. Hvilket dog ikke skulle hindre, at nationale domstole i de to lande efterfølgende kunne dømme for krigsforbrydelser med videre. Her leverer Harhoff god besked: 7.000 nazister blev således dømt ved tyske domstole, mens knap 4.000 japanerne fik en lignende afstraffelse ved japanske domstole.

Hvis man medregner både Vest- og Østttyskland kommer tallet på tyske dømte dog op på ca. 25.000. Hvad angår Eksjugoslavien foreligger der mig bekendt ingen informationer om nationale retsopgør, mens det fra Rwanda er oplyst, at over en mio. rwandere ved landets egne domstole, kaldet gacaca, er blevet dømt for deltagelse i eller medvirken til folkedrabet dér, noget ingen af de to bøger nævner.

Tribunalerne blev forløber for Den Internationale Straffedomstol (ICC), som siden 2002 har virket i Haag. Væsentlig er her at vide, at ICC's anklager såvel som en stat, der har ratificeret ICC's statut, eller FN's sikkerhedsråd kan rejse sager for domstolen.

Både ved de to nævnte tribunaler og ICC er der oprettet et særligt beskyttelsesprogram for vidner, idet de tiltalte eller deres medsammensvorne i flere tilfælde har truet vidnerne til at vidne falsk - nogle er endog blevet dræbt efter vidneforklaring. Beskyttelsen består $i$, at vidner tillades at afgive forklaring under pseudonym eller for lukkede døre.

ICC er ikke kun en straffedomstol, men kan også tildele ofrene for de grusomme forbrydelser godtgørelser, som pålægges de dømte eller afholdes af en særlig Trust Fund. (Det skete således ved dommen over den skyldige i omfattende ødelæggelser af middelalderlige muslimske bygningsværker med videre i Timbuktu, afsagt i 2017 efter Harhoff-bogens udgivelse). 
Mens altså tribunalerne og ICC i det væsentlige har dømt personer for disses krænkelser af, hvad der falder ind under den humanitære folkeret, eksisterer der ikke noget internationalt organ til at afsige straffedomme for menneskeretskrænkelser. Den Europæiske Menneskerettighedsdomstol i Strasbourg tilkender udelukkende erstatninger eller godtgørelser til personer, foreninger eller partier, hvis rettigheder efter den europæiske menneskerettighedskonvention er krænkede. Efter sager mod de enkelte medlemsstater er disse forpligtede til at betale de beløb, som skal udredes efter domstolens fastsættelse.

Modsat er et statsligt ansvar ikke en forudsætning for at rejse sag ved ICC, og to af de ganske få domme, denne domstol har afsagt, har netop ikke drejet sig om statsligt ansvarlige, men krigsherrer.

I betragtning af at Strasbourg-domstolen er den travleste af disse internationale instanser kunne en smule statistik måske være på sin plads, men det leverer ingen af bøgerne. Siden denne domstol begyndte sin virksomhed i 1959, har den afsagt omkring 20.000 domme, for tiden skriver den sig for omkring 1.000 om året. I langt de fleste er der tale om krænkelse af en eller flere af konventionens ca. 30 rettigheder.

Langstrakt sagsbehandling er den regel i konventionen, domstolen hyppigst har fundet overtrådt. Rusland og Tyrkiet har vekselvis indskrevet sig for flest domme på årsbasis. Henriksen henviser interessant til en britisk dom, hvor domstolen påpeger, at reformer eller fornyelser i samfundet vil blive hindret, hvis den ikke bruger den såkaldte dy- namiske fortolkning af konventionen, dvs. afsigelse af domme på basis af den situation, der hersker på tidspunktet for dommen.

\section{Den nationale skønsmargin}

Netop denne form for fortolkning og ikke den, der ville tage udgangspunktet for det tidspunkt, hvor konventionen blev til (i 1950), har været genstand for megen kritik bl.a. i Danmark. Dog har et princip, som domstolen har benyttet i et vist omfang, i virkeligheden begrænset den dynamiske fortolkning. Det er den såkaldte nationale skønsmargin, som ikke mindst har været brugt i en stribe britiske sager.

Heri ligger, at domstolen lidt frit gengivet har taget hensyn til visse Europaråds-staters 'særlige retsforhold', fx og ikke mindst på personrettens område. Handyside-dommen illustrerer dette meget klart: Den vedrørte den engelske oversættelse af den danske 'Lille røde for skoleelever', et frisproget anti-autoritært skrift, som britiske myndigheder frygtede ville fordærve unge mennesker.

Selv om den var udkommet i de fleste Europaråds-lande og såmænd også i Skotland, gav Strasbourg-domstolen ikke forlæggeren ret $i$, at hans ytringsfrihed efter konventionen var krænket ved bogens beslaglæggelse. Domstolen begrundede det med, at britiske myndigheder var bedre til at bedømme samfundsmoralen dér (suppleret af anm.).

Forholdet mellem resolutioner eller erklæringer og de folkeretligt bindende konventioner er klart beskrevet hos Henriksen. Han ser de vejledende resolutioner, ikke mindst dem som FN's 
Generalforsamling udsender, som en form for 'udkrystallisering' af folkeretlig sædvaneret, som danner basis for senere konventioner.

Uanset det skrevne ords magt, så er der dog eksempler på, at en telefonsamtale har bragt en konflikt til afslutning. Det gjaldt således den strid, der var opstået mellem Finland og Danmark, da Storebæltsbroen skulle bygges. Finland anlagde sag ved Den Internationale Domstol, fordi borerigge, som var bygget på finske skibsværfter, antoges ikke at kunne passere under den $65 \mathrm{~m}$ høje bro. De måler nemlig op til $200 \mathrm{~m}$ i højden. Danmark gik med til at betale Finland 90 mio. kr. som led i et forlig. Henriksen beretter, at forliget blev tilvejebragt gennem en telefonsamtale mellem Finlands og Danmarks statsministre.

\section{Hårde og bløde forpligtelser}

Det fortjener vel en overvejelse, at folkeretten i princippet opererer med to slags regler: de 'bløde' normer (typisk resolutioner, deklarationer, henstillinger), som staterne kan følge, og de bindende konventioner (traktater, pagter mv.), som de skal følge.

Rækkevidden af sidstnævnte er dog ofte til at overse, eftersom fortolkningerne er mange, og der kniber med at 'straffe' stater. Man har imidlertid et hjælpemiddel frem for ligefrem at gå $\mathrm{i}$ krig: Sanktioner, som i Iraks tilfælde, blev en forløber for omverdenens militære reaktion på Iraks invasion i Kuwait med henblik på at opsluge denne stat. Løbende er Rusland fx udsat for sanktioner på grund af sin erobring af den ukrainske halvø Krim. Som Henriksen beskriver, er det ofte vanskeligt at lodde, om FN-sikkerhedsrådets resolutioner skal forstås som et egentlig påbud eller en henstilling.

Den nye folkeretlige norm, der i kort form kaldes 'R2P' - ansvaret hvad angår beskyttelse [af en truet befolkning] (Responsibility to Protect), vedtaget på et FN-verdenstopmøde i 2005 - er blevet misfortolket af mange.

For det første er det kun en folkeretligt norm, ikke en egentlig pligt, uanset at begge bøger betegner det som sådan. Det var udtryk for et kompromis, at man brugte det svagere, lidt svært definerlige udtryk 'ansvar' i stedet for at bruge de almindelige retlige begreber: pligt eller ret. FN og det internationale samfund gjorde en form for afbigt efter folkedrabene i Rwanda og Bosnien hvor FN var ude af stand til at beskytte - ved at tilsige befolkninger i fare for folkedrab, forbrydelser mod menneskeheden, krigsforbrydelser eller etnisk udrensning beskyttelse.

En folkeretlig legitimering af humanitær intervention - som $\mathrm{fx}$ den NATO uden FN-mandat foretog i Kosovo i 1999 - var der dog ikke tale om, uanset at mange støttede lige akkurat denne intervention, fordi et folkedrab på kosovoalbanerne efter alt at dømme blev forebygget. Da R2P i 2011 så lagdes til grund for NATO-bombardementer af Libyen efter et folkeligt oprør mod diktatoren Muammar Gaddafi, og træfningerne udviklede sig til egentlig nedkæmpelse af regimet, vendte mange stater sig herimod.

Der er mængder af solid viden at hente i Harhoffs og Henriksens bøger, blot kniber det noget med at få et over- 
blik over de konflikter, som folkeretten eventuelt skal afhjælpe, især fordi der ikke nødvendigvis gives en kort letfattelig beskrivelse af dem. Der benyttes også forkortelser, som det er besværligt at finde betydningen af.

Mere generelt kan man om begge de to bøger sige, at deres stikordsregistre er særdeles vanskelige at finde rundt i og præget af stor inkonsekvens. I nogle tilfælde skal man søge internationale organisationer under deres fulde navn, $\mathrm{i}$ andre under deres akronym; institutioner under organisationer kan dels findes under den pågældende organisation, $\mathrm{i}$ andre tilfælde som selvstændigt opslagsord. Ingen af dem opererer med en forkortelsesliste.

Et logisk opbygget register tager vel i denne sammenhæng udgangspunkt $i$ begreberne, og en del af de væsentlige er da også stikord, men hos Harhoff må man således mangle sådanne begreber som fredsbevarende FN-styrker, fastlandssokkel, stat (definition), statssuccession, sanktioner, EU-domstolen, proportionalitetsprincippet, den nationale skønsmargin.

Erindrer man personlig en internationalt afgjort retssag ved dens personeller statstilknytning, kan man eksempelvis ikke let finde $\mathrm{fx}$ Nicaragua-sagen, Østgrønlandssagen, Corfu Channel-sagen eller Jersild-sagen.

\section{Statsbegrebet}

I den lille schweiziske bog, Völkerrecht kompakt, gives der god besked om statsbegrebet, altså de tre forudsæt- ninger for, at man kan tale om en stat i folkeretten:

1) Et statsfolk, dvs. en veldineret befolkning (uanset dens størrelse); hvem, der så bliver statsborgere her og der, afgøres efter enten jus soli-princippet, dvs. i hvilket land man er født, eller efter jus sanguinis, dvs. efter hvem, der er forældre

2) Et afgrænset territorium, uden risiko for at blive erobret $\mathrm{f} x$ af en nabostat.

3) En faktisk myndighedsudøvelse, fx opkrævelse af skatter.

Staterne har så meget forskellige regler for tilkendelse af statsborgerskab til fremmede. Ganske små stater så som Malta og Sct.Kitts/Nevis er begyndt på at sælge statsborgerskaber for beløb over én mio. kr. Det er kun den schweiziske bog, der kommer ind på alt dette.

Mange vil sikkert finde det folkeretsstridigt. Men alle bøger giver forskellige doser af folkerettens mangfoldighed: Harhoff tilsætter en del vigtig historisk ballast, Henriksen giver et bredt billede ved at medtage en del organisationer og internationale aftaler om økonomi og miljø, og den schweiziske bog vil nok af nogle blive betragtet som en slags pixiebog om folkeret, men den har dog gode konkrete eksempler og oversigter.

Man er mættet og kan dog komme i tanke om emner, som er udeladt - så som statsløshed. Er man ikke for kræsen, kan man eventuelt gå på nettet eller tjekke efter i leksika. 